\title{
Nitrite accumulation inside sludge flocs significantly influencing nitrous oxide production by ammonium-oxidizing bacteria
}

\author{
Chen, Xueming; Yuan, Zhiguo; Ni, Bing-Jie
}

Published in:

Water Research

Link to article, DOI:

10.1016/j.watres.2018.06.025

Publication date:

2018

Document Version

Peer reviewed version

Link back to DTU Orbit

Citation (APA):

Chen, X., Yuan, Z., \& Ni, B-J. (2018). Nitrite accumulation inside sludge flocs significantly influencing nitrous oxide production by ammonium-oxidizing bacteria. Water Research, 143, 99-108.

https://doi.org/10.1016/j.watres.2018.06.025

\section{General rights}

Copyright and moral rights for the publications made accessible in the public portal are retained by the authors and/or other copyright owners and it is a condition of accessing publications that users recognise and abide by the legal requirements associated with these rights.

- Users may download and print one copy of any publication from the public portal for the purpose of private study or research.

- You may not further distribute the material or use it for any profit-making activity or commercial gain

- You may freely distribute the URL identifying the publication in the public portal 


\section{Accepted Manuscript}

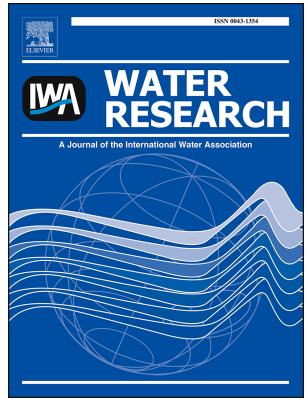

Nitrite accumulation inside sludge flocs significantly influencing nitrous oxide production by ammonium-oxidizing bacteria

Xueming Chen, Zhiguo Yuan, Bing-Jie Ni

PII: S0043-1354(18)30475-5

DOI: $\quad$ 10.1016/j.watres.2018.06.025

Reference: WR 13852

To appear in: Water Research

Received Date: 23 January 2018

Revised Date: 12 June 2018

Accepted Date: 13 June 2018

Please cite this article as: Chen, X., Yuan, Z., Ni, B.-J., Nitrite accumulation inside sludge flocs significantly influencing nitrous oxide production by ammonium-oxidizing bacteria, Water Research (2018), doi: 10.1016/j.watres.2018.06.025.

This is a PDF file of an unedited manuscript that has been accepted for publication. As a service to our customers we are providing this early version of the manuscript. The manuscript will undergo copyediting, typesetting, and review of the resulting proof before it is published in its final form. Please note that during the production process errors may be discovered which could affect the content, and all legal disclaimers that apply to the journal pertain. 


\section{Graphical Abstract}

$\mathrm{NO}_{2}{ }^{-}$accumulation inside nitrifying flocs

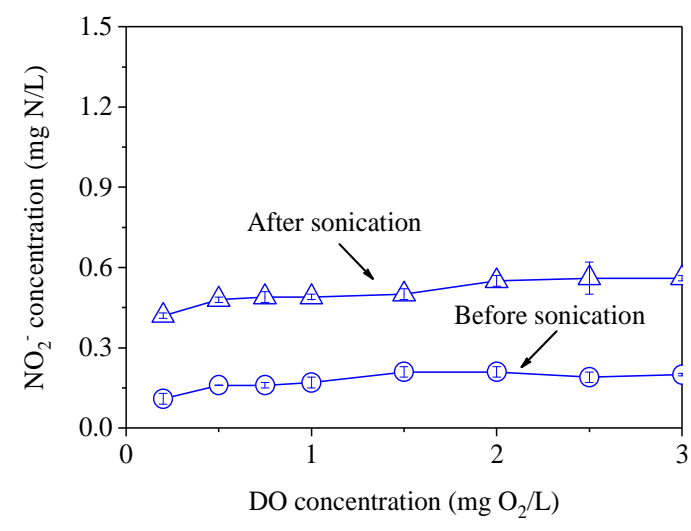

$\mathrm{N}_{2} \mathrm{O}$ production and pathway contribution

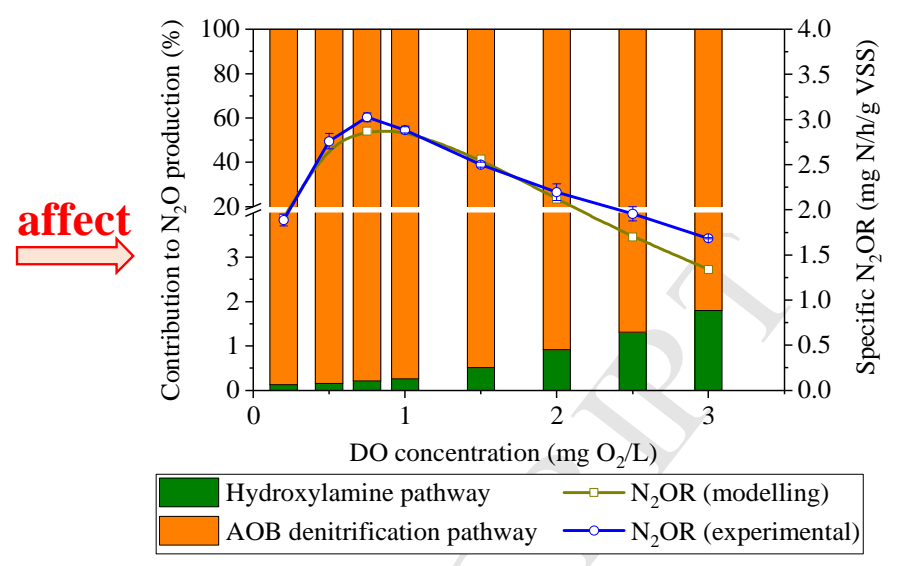


1

2

3

4

5

$6 \quad{ }^{1}$ Advanced Water Management Centre, The University of Queensland, St. Lucia, Brisbane, QLD

$7 \quad 4072$, Australia

$8 \quad{ }^{2}$ Process and Systems Engineering Center (PROSYS), Department of Chemical and Biochemical

9 Engineering, Technical University of Denmark, 2800 Kgs. Lyngby, Denmark

10

11

12

\section{Nitrite Accumulation inside Sludge Flocs Significantly Influencing Nitrous Oxide}

\section{Production by Ammonium-Oxidizing Bacteria}

$$
\text { Xueming Chen }{ }^{1,2} \text {, Zhiguo Yuan }{ }^{1} \text {, Bing-Jie } \mathrm{Ni}^{1, *}
$$

\section{1 *Corresponding author:}

2 Dr. Bing-Jie Ni, Phone: + 6173346 3230, E-mail: bingjieni@gmail.com 


\section{ABSTRACT}

This work aims to clarify the role of potential nitrite $\left(\mathrm{NO}_{2}{ }^{-}\right)$accumulation inside sludge flocs in $\mathrm{N}_{2} \mathrm{O}$ production by ammonium-oxidizing bacteria (AOB) at different dissolved oxygen (DO) levels with focus on the conditions of no significant bulk $\mathrm{NO}_{2}{ }^{-}$accumulation $(<0.2 \mathrm{mg} \mathrm{N} / \mathrm{L})$. To this end, an augmented nitrifying sludge with much higher abundance of nitrite-oxidizing bacteria (NOB) than AOB was enriched and then used for systematically designed batch tests, which targeted a range of DO levels from 0 to $3.0 \mathrm{mg} \mathrm{O} / \mathrm{L}$ at a fixed ammonium concentration of $10 \mathrm{mg} \mathrm{N} / \mathrm{L}$. A two-pathway $\mathrm{N}_{2} \mathrm{O}$ model was applied to facilitate the interpretation of batch experimental data, thus shedding light on the relationships between $\mathrm{N}_{2} \mathrm{O}$ production pathways and key process parameters (i.e., $\mathrm{DO}$ and $\mathrm{NO}_{2}{ }^{-}$accumulation inside sludge flocs). The results demonstrated (i) the biomass specific $\mathrm{N}_{2} \mathrm{O}$ production rate firstly increased and then decreased with DO, with the maximum value of $3.03 \pm 0.05 \mathrm{mg} \mathrm{N} / \mathrm{h} / \mathrm{g}$ VSS obtained at DO level of 0.75 mg $\mathrm{O}_{2} / \mathrm{L}$, (ii) the AOB denitrification pathway for $\mathrm{N}_{2} \mathrm{O}$ production was dominant $(98.0 \%)$ at all DO levels tested even without significant bulk $\mathrm{NO}_{2}{ }^{-}$accumulation $(<0.2 \mathrm{mg} \mathrm{N} / \mathrm{L})$ observed in the system, but its contribution decreased with DO, (iii) DO had a positive impact on the hydroxylamine pathway for $\mathrm{N}_{2} \mathrm{O}$ production which therefore increased with $\mathrm{DO}$, and (iv) the nitrite accumulation existed inside the sludge flocs and induced significant $\mathrm{N}_{2} \mathrm{O}$ production from the AOB denitrification pathway.

Keywords: Nitrous oxide $\left(\mathrm{N}_{2} \mathrm{O}\right)$, nitrite accumulation, dissolved oxygen, production pathway, mathematical modelling 


\section{INTRODUCTION}

Wastewater treatment plants (WWTPs) have been identified as a significant source of nitrous oxide $\left(\mathrm{N}_{2} \mathrm{O}\right) . \mathrm{N}_{2} \mathrm{O}$ is not only a significant greenhouse gas with a global warming effect 300 times stronger than carbon dioxide but also a major scavenger of stratospheric ozone leading to ozone layer depletion (IPCC 2013, Ravishankara et al. 2009, Strokal and Kroeze 2014). During biological nitrogen removal from wastewater, nitritation, which requires oxygen as the electron acceptor to convert ammonium $\left(\mathrm{NH}_{4}{ }^{+}\right)$to nitrite $\left(\mathrm{NO}_{2}{ }^{-}\right)$via hydroxylamine $\left(\mathrm{NH}_{2} \mathrm{OH}\right)$ as an intermediate, is mediated by ammonium-oxidizing bacteria (AOB) and regarded as the major contributor to $\mathrm{N}_{2} \mathrm{O}$ production (Kampschreur et al. 2009, Law et al. 2012). Two main pathways are involved in $\mathrm{N}_{2} \mathrm{O}$ production by $\mathrm{AOB}$ : (i) $\mathrm{N}_{2} \mathrm{O}$ as a by-product of incomplete oxidation of $\mathrm{NH}_{2} \mathrm{OH}$ to $\mathrm{NO}_{2}^{-}$, called the $\mathrm{NH}_{2} \mathrm{OH}$ pathway and (ii) $\mathrm{N}_{2} \mathrm{O}$ as the final product of $\mathrm{AOB}$ denitrification with $\mathrm{NO}_{2}^{-}$as the terminal electron acceptor, known as the AOB denitrification pathway (Chandran et al. 2011). When present, ammonium-oxidizing archaea (AOA) might also contribute to $\mathrm{N}_{2} \mathrm{O}$ production (Hu et al. 2015). Different responses of $\mathrm{N}_{2} \mathrm{O}$ contributing pathways to different operational conditions and process parameters have been reported to be responsible for the wide variation of $\mathrm{N}_{2} \mathrm{O}$ emission factors recorded (Massara et al. 2017, Su et al. 2017). Of all process parameters, dissolved oxygen (DO) and $\mathrm{NO}_{2}^{-}$have been identified as two key ones influencing $\mathrm{N}_{2} \mathrm{O}$ production by $\mathrm{AOB}$ during nitritation. However, consensus has not yet been reached in terms of the effects of $\mathrm{DO}$ and $\mathrm{NO}_{2}{ }^{-}$on $\mathrm{N}_{2} \mathrm{O}$ production by $\mathrm{AOB}$.

In general, both full-scale and lab-scale studies have presented a positive relationship between $\mathrm{N}_{2} \mathrm{O}$ production by $\mathrm{AOB}$ and $\mathrm{NO}_{2}{ }^{-}$concentration (Foley et al. 2010, Gong et al. 2012, Kim et al. 2010, Shen et al. 2014, Shiskowski and Mavinic 2006, Wunderlin et al. 2012), which might be 
explained by the favored AOB denitrification pathway at higher $\mathrm{NO}_{2}{ }^{-}$concentration (Peng et al. 2015). On the contrary, Law et al. (2013) observed an inhibitory effect of $\mathrm{NO}_{2}^{-}$on $\mathrm{N}_{2} \mathrm{O}$ production by $\mathrm{AOB}$ in a nitritation system at $\mathrm{NO}_{2}{ }^{-}$concentration of higher than $50 \mathrm{mg} \mathrm{N} / \mathrm{L}$. This phenomenon might be the result of the enhanced $\mathrm{NH}_{2} \mathrm{OH}$ pathway and the decreased contribution of the AOB denitrification pathway for $\mathrm{N}_{2} \mathrm{O}$ production at elevated $\mathrm{NO}_{2}^{-}$ concentration, which was supported by a modelling study by Ni et al. (2014). Similarly, some studies have reported the increased $\mathrm{N}_{2} \mathrm{O}$ production with decreased $\mathrm{DO}$ concentration due to the enhanced AOB denitrification pathway under oxygen limiting conditions (Kampschreur et al. 2008, Peng et al. 2014). In contrast, different correlations between $\mathrm{N}_{2} \mathrm{O}$ production and $\mathrm{DO}$ concentration have been discovered by other studies (Tallec et al. 2006, Yang et al. 2009). The discrepancy might be related to the facilitated $\mathrm{N}_{2} \mathrm{O}$ production via the $\mathrm{NH}_{2} \mathrm{OH}$ pathway under aerobic conditions when DO concentration was high (Chandran et al. 2011).

As discussed by Peng et al. (2014), the common presence of heterotrophic bacteria (HB) complicates the accurate deduction of the $\mathrm{N}_{2} \mathrm{O}$ production profile by AOB. The metabolisms of $\mathrm{HB}$ involve $\mathrm{N}_{2} \mathrm{O}$ as an obligate intermediate, with its production and consumption also affected by both DO and $\mathrm{NO}_{2}^{-}$(e.g., Wunderlin et al. (2012), Yang et al. (2009)). Moreover, difficulty remains in separating the effect of DO from that of $\mathrm{NO}_{2}{ }^{-}$, considering their close relationship in the metabolisms of AOB. For example, when investigating the impact of $\mathrm{DO}$ on $\mathrm{N}_{2} \mathrm{O}$ production by $\mathrm{AOB}$, variation of $\mathrm{DO}$ concentration usually brings about variable $\mathrm{NO}_{2}{ }^{-}$accumulation, thus incurring an accompanying effect of $\mathrm{NO}_{2}^{-}$. By adding extra sludge enriched with nitriteoxidizing bacteria (NOB) to nitrifying sludge (consisting of both $\mathrm{AOB}$ and $\mathrm{NOB}$ ) to consume $\mathrm{NO}_{2}{ }^{-}$produced by $\mathrm{AOB}$, Peng et al. (2014) attempted to single out the sole effect of DO on $\mathrm{N}_{2} \mathrm{O}$ 
production by $\mathrm{AOB}$. However, the interference of $\mathrm{NO}_{2}{ }^{-}$could not be completely ruled out in view of the low but still apparent $\mathrm{NO}_{2}{ }^{-}$accumulation $(1.5 \sim 2.0 \mathrm{mg} \mathrm{N} / \mathrm{L})$ observed in the bulk liquid, especially given the low $\mathrm{NO}_{2}{ }^{-}$affinity constant for the AOB denitrification pathway (e.g., $0.14 \mathrm{mg} \mathrm{N} / \mathrm{L}$ in Ni et al. (2011)). Besides, as microbial activities mainly take place inside the nitrifying sludge flocs, there usually exists substrate concentration gradient within the domain of certain floc sizes. Therefore, the concentration of $\mathrm{NO}_{2}^{-}$produced by AOB inside the nitrifying sludge flocs might be higher than that measured in the bulk liquid. This means that $\mathrm{NO}_{2}^{-}$might still exert an impact on $\mathrm{N}_{2} \mathrm{O}$ production even in the absence of significant $\mathrm{NO}_{2}{ }^{-}$detected in the bulk liquid. To the best of our knowledge, there has been no study reported looking into whether the potential nitrite accumulation inside nitrifying sludge flocs, if any, would affect $\mathrm{N}_{2} \mathrm{O}$ production by $\mathrm{AOB}$. This overlook of the role of potential nitrite accumulation in floccular structure in $\mathrm{N}_{2} \mathrm{O}$ production is mainly due to the generally low nitrite accumulation potentially present in floccular structure when compared with granular structure.

Therefore, this work aims to clarify the role of potential nitrite accumulation inside sludge flocs in $\mathrm{N}_{2} \mathrm{O}$ production by $\mathrm{AOB}$ at different DO levels for the first time, focusing on the conditions of no significant bulk $\mathrm{NO}_{2}{ }^{-}$accumulation $(<0.2 \mathrm{mg} \mathrm{N} / \mathrm{L})$. To get rid of $\mathrm{NO}_{2}{ }^{-}$accumulation in the bulk liquid when varying DO, an augmented nitrifying culture comprising mainly NOB with much lesser coexistence of AOB in same flocs was enriched. With the potential contribution of $\mathrm{HB}$ to either consumption or production of $\mathrm{N}_{2} \mathrm{O}$ being identified, batch tests were then conducted to quantify $\mathrm{N}_{2} \mathrm{O}$ production at different DO levels using the augmented nitrifying sludge. To determine the nitrite content potentially accumulating inside the nitrifying sludge flocs, highoutput sonication was employed to treat samples collected during batch tests in order to release 
nitrite from the flocs. Mathematical modelling was also applied to gain insight into the contributions of the two known $\mathrm{N}_{2} \mathrm{O}$ production pathways by AOB. This work is expected to shed more light on the $\mathrm{N}_{2} \mathrm{O}$ production dynamics in activated sludge flocs, which remain as the main form of sludge adopted at WWTPs for nitrogen removal technologies, such as nitrification and denitrification which has been reported to exhibit significant $\mathrm{N}_{2} \mathrm{O}$ emissions (Massara et al. 2017).

\section{MATERIALS AND METHODS}

\subsection{Enrichment of Augmented Nitrifying Culture}

A sequencing batch reactor (SBR) seeded with sludge collected from Luggage Point WWTP in Brisbane, Australia was operated in the lab with temperature controlled at $22.0-23.0{ }^{\circ} \mathrm{C}$. The SBR had a working volume of $8 \mathrm{~L}$ and was operated with a cycle time of $6 \mathrm{~h}$ consisting of 260 min aerobic feeding, $25 \mathrm{~min}$ aeration, $0.5 \mathrm{~min}$ sludge wasting, $50 \mathrm{~min}$ settling and $24.5 \mathrm{~min}$ decanting. The 260 min aerobic feeding period was further divided into 52 cycles and each cycle consisted of 1 min feeding with aeration and 4 min aeration without feeding. The purpose of this setup was to avoid potential nitrite inhibition during the enrichment process. $2 \mathrm{~L}$ of synthetic wastewater was fed to the SBR during each $6 \mathrm{~h}$ cycle, resulting in a hydraulic retention time (HRT) of $24 \mathrm{~h}$. By wasting $80 \mathrm{~mL}$ of mixed sludge during the $0.5 \mathrm{~min}$ sludge wasting period, the solids retention time (SRT) was kept around 13 days. With the programmed logic controller (PLC) installed, DO in the SBR, which was continuously monitored online with a miniCHEM DO meter, was controlled between 2.5 and $3.0 \mathrm{mg} \mathrm{O} / \mathrm{L}$ during the feeding and aerobic phases using compressed air. $\mathrm{pH}$ was measured on a miniCHEM $\mathrm{pH}$ meter and regulated between 7.4 
and 7.6 during the feeding and aerobic phases by dosing $1 \mathrm{M} \mathrm{NaHCO}_{3}$ or $1 \mathrm{M} \mathrm{HCl}$ through a small peristaltic pump.

To obtain the augmented nitrifying sludge with much higher abundance of NOB than AOB, the feeding concentration of $\mathrm{NO}_{2}^{-}$in the form of $\mathrm{NaNO}_{2}$ was subject to stepwise increase from 250 mg N/L to $1250 \mathrm{mg} \mathrm{N} / \mathrm{L}$ while that of $\mathrm{NH}_{4}{ }^{+}$in the form of $\mathrm{NH}_{4} \mathrm{HCO}_{3}$ was fixed at $250 \mathrm{mg} \mathrm{N} / \mathrm{L}$. This decreasing $\mathrm{NH}_{4}{ }^{+}-\mathrm{N} / \mathrm{NO}_{2}{ }^{-}-\mathrm{N}$ ratio from 250:500 (i.e., 1:2) to 250:1500 (i.e., 1:6) in the feed $\left(\mathrm{NO}_{2}{ }^{-} \mathrm{N}\right.$ included that produced by $\left.\mathrm{AOB}\right)$ significantly favored the growth of $\mathrm{NOB}$ over AOB in the nitrifying sludge. In addition to $\mathrm{NaNO}_{2}$ and $\mathrm{NH}_{4} \mathrm{HCO}_{3}$, the synthetic wastewater fed to the SBR also contained (per liter) $2.0 \mathrm{~g} \mathrm{NaHCO}_{3}, 1.3 \mathrm{~g} \mathrm{~K}_{2} \mathrm{HPO}_{4}$ and $1.3 \mathrm{~g} \mathrm{KH}_{2} \mathrm{PO}_{4}$ as well as $2 \mathrm{~mL}$ of trace element solution with composition specified in Peng et al. (2014).

At the time when the batch tests detailed in the next section were conducted, the SBR was already operated in steady state for more than 2 months, as evidenced by $100 \%$ conversion of feeding $\mathrm{NO}_{2}^{-}$and $\mathrm{NH}_{4}{ }^{+}$to $\mathrm{NO}_{3}{ }^{-}$at the end of each cycle as well as the stable mixed liquor volatile suspended solids (MLVSS) concentration of $1523 \pm 40 \mathrm{mg} / \mathrm{L}(\mathrm{n}=11)$ in the SBR. Both the settling velocity index $(\sim 50)$ and morphology (i.e., tawny flocs with size D50 of $114 \mu \mathrm{m})$ of the augmented nitrifying sludge flocs were determined to be consistent with the typical activated sludge flocs. The dominance of NOB over $\mathrm{AOB}$ in the augmented nitrifying sludge was confirmed by fluorescence in-situ hybridization (FISH) analysis (see Figure S1 in the supporting information (SI)) which was conducted according to the procedure applied by Law et al. (2011). The biovolume fraction of the bacteria of interest was determined by analyzing 10 FISH images using DAIME version 1.3 (Daims et al. 2001) which returns mean percentages with standard 
deviations. The FISH analysis indicated that $35 \pm 3 \%$ of the EUBMix probe targeted cells bound to NSO1225 probe, representing beta-proteobacterial AOB including Nitrosospira, Nitrosococcus and Nitrosomonas genera, while $52 \pm 5 \%$ of the EUBMix probe targeted cells bound to NIT3 probe, specific for NOB belonging to Nitrobacter genus. NOB belonging to Nitrospira genus was indicated to be absent or of extremely low abundance, considering the fact that no signals were detected for Ntspa662 and Ntspa712 probes. The 16S rRNA gene pyrosequencing analysis was also conducted. The DNA of the augmented nitrifying sludge was extracted using a FastDNA SPIN Kit for Soil (MP Biomedicals, USA) according to the manufacturer's instruction. The extracted DNA sample was sent to Australian Centre for Ecogenomics (ACE) for $16 \mathrm{~S}$ Amplicon sequencing by Illumina Miseq Platform. The result was analyzed according to Hülsen et al. (2016) and showed an AOB (Nitrosomonas):NOB (Nitrobacter) ratio of $1: 2.3$ in terms of operational taxonomic unit (OTU), which was comparable to the FISH result. The absence of Nitrospira detected by pyrosequencing was also consistent with the FISH analysis.

\subsection{Batch Experiments}

To clarify the role of potential nitrite accumulation inside sludge flocs in $\mathrm{N}_{2} \mathrm{O}$ production by AOB at different DO levels without significant bulk $\mathrm{NO}_{2}{ }^{-}$accumulation $(<0.2 \mathrm{mg} \mathrm{N} / \mathrm{L})$, nine sets of triplicate batch tests were carried out, targeting nine DO levels, i.e., 0, 0.2, 0.5, 0.75, 1.0, 1.5, 2.0, 2.5 and $3.0 \mathrm{mg} \mathrm{O}_{2} / \mathrm{L}$. For each batch test, $0.16 \mathrm{~L}$ of mixed liquor was withdrawn from the SBR and diluted to $1 \mathrm{~L}$ using decant from the SBR, thus rendering a final concentration of mixed liquor suspended solids (MLSS) of $320 \mathrm{mg} / \mathrm{L}$ and its volatile fraction (i.e., MLVSS) of $295 \mathrm{mg} / \mathrm{L}$. The diluted mixed liquor was adjusted to $\mathrm{pH}$ of 7.5 and placed in a $1.3 \mathrm{~L}$ batch reactor with a 
sealable lid on a magnetic stirrer $(200 \mathrm{rpm})$ at $22.0-23.0^{\circ} \mathrm{C}$. A miniCHEM DO meter and a miniCHEM pH meter were mounted in the batch reactor, enabling continuous online monitoring of DO and $\mathrm{pH}$, respectively. During the entire experiment, DO concentration was controlled at the designed level with a gas mixture of $\mathrm{N}_{2}$ and air. The $\mathrm{N}_{2}$ flow rate and air flow rate were adjusted using two mass flow controllers (Smart-Trak 50 series, Sierra) with the total gas flow rate being controlled constantly at $0.5 \mathrm{~L} / \mathrm{min}$ : each change in the $\mathrm{N}_{2}$ flow rate was compensated for by an equivalent change in the air flow rate. $\mathrm{pH}$ was maintained at 7.5 by dosing $0.1 \mathrm{M} \mathrm{HCl}$ manually using a dropper seamlessly attached to the batch reactor.

Each batch test lasted for 60 min including 10 min control phase and 50 min experimental phase.

The same DO level was applied to both phases. In the control phase, no $\mathrm{NH}_{4}{ }^{+}$was added and any $\mathrm{N}_{2} \mathrm{O}$ production could therefore be attributed to heterotrophic activity. In the following experimental phase of all batch tests, the $\mathrm{NH}_{4}{ }^{+}$concentration was controlled at $10 \mathrm{mg} \mathrm{N} / \mathrm{L}$ through manually adding a stock solution of $22.6 \mathrm{~g} / \mathrm{L} \mathrm{NH}_{4} \mathrm{HCO}_{3}$ and $24 \mathrm{~g} / \mathrm{L} \mathrm{NaHCO}$ at an interval of $10 \mathrm{~min}$, with amount determined according to the method described in Peng et al. (2014). During each test, $7.5 \mathrm{~mL}$ mixed liquor sample was taken every $10 \mathrm{~min}$ using a syringe. $5.0 \mathrm{~mL}$ of the mixed liquor sample was immediately filtered through disposable Millipore filter $(0.22 \mu \mathrm{m}$ pore size $)$. Half of the $5.0 \mathrm{~mL}$ filtered sample was stored for liquid phase $\mathrm{N}_{2} \mathrm{O}$ measurement using a gas chromatograph (Agilent GC7890A, Agilent Technologies, Santa Clara, California, USA) while the other half for bulk $\mathrm{NO}_{2}{ }^{-}, \mathrm{NH}_{4}{ }^{+}$and $\mathrm{NO}_{3}{ }^{-}$analyses. The remaining 2.5 $\mathrm{mL}$ of the mixed liquor sample was firstly treated with sonication using Branson Sonifier 250 at the maximum amplitude output of as high as $100 \%$ for 3 min consistently to release substances accumulating inside sludge flocs to the liquid phase (Mozo et al. 2016, Salsabil et al. 2009). The 
effectiveness of this sonication setup was proved by the change in the particle size distribution D50 measured using the Malvern Mastersizer/E, which significantly decreased from $114 \mu \mathrm{m}$ to $10 \mu \mathrm{m}$ after high-output sonication treatment. The treated sample was then filtered through disposable Millipore filter $(0.22 \mathrm{~mm}$ pore size $)$ to measure the post-sonication $\mathrm{NO}_{2}^{-}, \mathrm{NH}_{4}{ }^{+}$and $\mathrm{NO}_{3}{ }^{-}$concentrations. During the entire batch test with a constant gas flow rate of $0.5 \mathrm{~L} / \mathrm{min}, \mathrm{N}_{2} \mathrm{O}$ concentration in the gas phase of the batch reactor was recorded consistently with a URAS 26 infrared photometer (Advance Optima Continuous Gas Analyzer AO2020 series, ABB) following the instruction reported by Peng et al. (2014). At the end of each batch test, $20 \mathrm{~mL}$ mixed liquor sample was taken in triplicate from the batch reactor to determine the concentrations of MLSS and MLVSS.

To evaluate the possible $\mathrm{N}_{2} \mathrm{O}$ consumption by $\mathrm{HB}$, four $\mathrm{N}_{2} \mathrm{O}$ consumption tests were also conducted at DO levels of $0.5,1.0,2.0$ and $3.0 \mathrm{mg} \mathrm{O} / \mathrm{L}$ using the same diluted augmented nitrifying sludge. The headspace in the batch reactor was removed by adding the same diluted augmented nitrifying sludge, and the URAS 26 infrared photometer was disconnected. Aeration was stopped after DO reached the designed level, and $1.5 \mathrm{~mL}$ of saturated $\mathrm{N}_{2} \mathrm{O}$ solution was added into the batch reactor. Afterwards the batch reactor was immediately sealed. Samples were taken every 10 min and immediately filtered for measurement of $\mathrm{N}_{2} \mathrm{O}$ concentration in the liquid phase. Then $\mathrm{N}_{2} \mathrm{O}$ consumption rate at each DO level was determined from the corresponding $\mathrm{N}_{2} \mathrm{O}$ concentration profile measured.

\subsection{Calculations}


The biomass specific ammonium oxidation rate (AOR), biomass specific $\mathrm{N}_{2} \mathrm{O}$ production rate $\left(\mathrm{N}_{2} \mathrm{OR}\right.$ ) and $\mathrm{N}_{2} \mathrm{O}$ emission factor (i.e., the ratio between the $\mathrm{N}_{2} \mathrm{O}$ nitrogen emitted and the ammonium nitrogen converted) were calculated for each batch test. The $\mathrm{N}_{2} \mathrm{O}$ nitrogen emitted was quantified as the integral of $\mathrm{N}_{2} \mathrm{O}$ emission rate calculated by multiplying the gas phase $\mathrm{N}_{2} \mathrm{O}$ concentration measured on the URAS 26 infrared photometer and the known gas flow rate over time. It should be noted that only steady-state AOR, $\mathrm{N}_{2} \mathrm{OR}$ and $\mathrm{N}_{2} \mathrm{O}$ emission factor during the second half of the 60 min testing period were accounted for in this work. In view of the nearly constant $\mathrm{NH}_{4}{ }^{+}$concentration during each batch test achieved by periodical dosing of $\mathrm{NH}_{4} \mathrm{HCO}_{3}$, the converted $\mathrm{NH}_{4}{ }^{+}$for AOR was calculated according to the exact same amount of $\mathrm{NH}_{4}{ }^{+}$added during each 10 min period. The calculation of $\mathrm{N}_{2} \mathrm{OR}$ was based on the accumulative amount of $\mathrm{N}_{2} \mathrm{O}$ emitted during the 30 min steady state. The biomass specific AOR ( $\mathrm{mg} \mathrm{NH}_{4}{ }^{+}-\mathrm{N} / \mathrm{h} / \mathrm{g}$ VSS) and biomass-specific $\mathrm{N}_{2} \mathrm{OR}$ ( $\mathrm{mg} \mathrm{N}_{2} \mathrm{O}-\mathrm{N} / \mathrm{h} / \mathrm{g}$ VSS) were calculated by normalizing the AOR and $\mathrm{N}_{2} \mathrm{OR}$ data with the MLVSS concentration of the diluted augmented nitrifying sludge. The $\mathrm{N}_{2} \mathrm{O}$ emission factor was calculated as the ratio between $\mathrm{N}_{2} \mathrm{OR}$ and AOR obtained for each batch test.

\subsection{Chemical Analyses}

$\mathrm{NO}_{2}^{-}, \mathrm{NH}_{4}^{+}$and $\mathrm{NO}_{3}^{-}$concentrations were analysed using a Lachat QuikChem8000 Flow Injection Analyser (Lachat Instrument, Milwaukee). MLSS and MLVSS concentrations were measured according to the standard methods (APHA 1998).

\subsection{Model-Based Interpretation}

The two-pathway $\mathrm{N}_{2} \mathrm{O}$ model proposed by $\mathrm{Ni}$ et al. (2014), which links the oxidation and reduction processes through a pool of reduced form (Mred) and oxidized form (Mox) of electron 
carriers, was employed in this work to interpret the experimental data. In the model, both the AOB denitrification pathway and the $\mathrm{NH}_{2} \mathrm{OH}$ pathway consume Mred and generate the equivalent level of Mox. Though other processes such as ammonium oxidation, $\mathrm{NH}_{2} \mathrm{OH}$ oxidation and $\mathrm{O}_{2}$ reduction complicate the turnover between Mred and Mox, the total level of electron carriers is assumed to remain constant. Additionally, an oxygen inhibition term was included to consider the impact of DO on the AOB denitrification pathway (Ni et al. 2011, Pocquet et al. 2016). The soluble and particulate model components are listed in Table S1 in the SI, while the stoichiometric/kinetic matrix and the parameters of the two-pathway $\mathrm{N}_{2} \mathrm{O}$ model are summarized in Tables S2 and S3, respectively. The augmented nitrifying sludge flocs were modelled as a floc-based particle system in consideration of inside substrate diffusion using the AQUASIM software package (Reichert 1998). Similar to Volcke et al. (2010), flocs were modelled to be spherical in shape, i.e., as particles. Only radial diffusion transport described by Fick's law was considered, and all relevant diffusion coefficients were taken from Sabba et al. (2015). The purpose of this modelling setup, different from Peng et al. (2014), was to enable the investigation into the role of potential nitrite accumulation inside sludge flocs in $\mathrm{N}_{2} \mathrm{O}$ production by AOB. A similar particle-based modelling setup has been applied to simulate activated sludge flocs considering their structural characteristics as aggregates of microbial origin (Li and Bishop 2003a, Li and Bishop 2003b) so that microenvironments inside sludge flocs could be described. A particle size distribution was avoided in this work to reduce the complexity of numerical computations whilst retaining a reasonably good understanding of the system ( $\mathrm{Ni}$ et al. 2009). Therefore, following the method of $\mathrm{Ni}$ et al. (2009), the number of the augmented nitrifying sludge flocs in the reactor was calculated, assuming a uniform particle size of $114 \mu \mathrm{m}$ (i.e., D50) and a density of $50000 \mathrm{mg} \mathrm{COD/L} \mathrm{(Koch} \mathrm{et} \mathrm{al.} \mathrm{2000).}$ 
For the modelling, the biomass concentrations of $\mathrm{AOB}$ and $\mathrm{NOB}$ in the augmented nitrifying

sludge were determined based on the measured MLVSS concentrations together with the relative biomass abundance quantified by $16 \mathrm{~S}$ rRNA gene pyrosequencing (i.e., AOB:NOB ratio of 1:2.3). Following the common modelling practice, a conversion factor of 1.42 (i.e., ratio between COD and VSS) was used to determine biomass concentration as COD (Contreras et al. 2002). In view of the incapability of the model configured with parameters directly taken from reported literature (see Table S3 in the SI) to describe the batch experimental data in this work (data not shown), a model calibration was imperative to obtain a reliable model for understanding the $\mathrm{N}_{2} \mathrm{O}$ production by $\mathrm{AOB}$ in the augmented nitrifying sludge of this work. Prior to model calibration, a sensitivity analysis was firstly conducted using the AQUASIM built-in algorithms to locate the most important parameter(s) which could be reliably estimated under the batch experimental conditions. The "absolute-relative" sensitivity function was used in this work, and the base values of parameters and initial conditions were set according to the literature reported values (see Table S3 in the SI) and the specific batch experimental settings used for model calibration. The sensitive parameter(s) identified by the sensitivity analysis was then calibrated using the batch tests at DO levels of $0.2,0.75,1.0,2.0$ and $3.0 \mathrm{mg} \mathrm{O}_{2} / \mathrm{L}$. Model validation was then conducted using batch tests at DO levels of $0.5,1.5$ and $2.5 \mathrm{mg} \mathrm{O}_{2} / \mathrm{L}$. For the model calibration/validation process, the profiles of $\mathrm{NO}_{2}^{-}, \mathrm{NH}_{4}{ }^{+}, \mathrm{DO}$, and $\mathrm{N}_{2} \mathrm{O}$ were used at the same time. Parameter estimation and parameter uncertainty evaluation, with 95\% confidence, were conducted according to Batstone et al. (2003). The confidence regions for parameter combinations were determined using a modified version of AQUASIM $2.1 \mathrm{~d}$ (Ge et al. 2010). Finally, the developed model was utilized to obtain insight into the role of potential nitrite 
accumulation inside sludge flocs in regulating the two pathways for $\mathrm{N}_{2} \mathrm{O}$ production by AOB under different DO concentration conditions.

\section{RESULTS}

\section{1. $\quad \mathrm{N}_{2} \mathrm{O}$ production at different $\mathrm{DO}$ levels without significant bulk nitrite accumulation}

As shown in Figure 1, experimental data for all batch tests in this work exhibited similar trends. No $\mathrm{N}_{2} \mathrm{O}$ was detected in both gas and liquid phases during the first 10 min control phase, indicating the negligible $\mathrm{N}_{2} \mathrm{O}$ production contribution of heterotrophic denitrification due to the unavailability of organic carbon source. The potential $\mathrm{N}_{2} \mathrm{O}$ consumption by $\mathrm{HB}$ was also ruled out by $\mathrm{N}_{2} \mathrm{O}$ consumption control tests with results shown in Figure $\mathrm{S} 2$. Therefore, any $\mathrm{N}_{2} \mathrm{O}$ change in the following phase of batch tests would be solely ascribed to the activities of AOB. Applicable to both gas phase and liquid phase data, $\mathrm{N}_{2} \mathrm{O}$ concentration reached steady-state level in about $10 \mathrm{~min}$ after dosage of $10 \mathrm{mg} \mathrm{N} / \mathrm{L}$ of $\mathrm{NH}_{4}{ }^{+}$under all DO concentration conditions studied except for DO level of $3.0 \mathrm{mg} \mathrm{O} / \mathrm{L}$ (i.e., Figure $1 \mathrm{H}$ ). As illustrated in Figure 1, $\mathrm{NH}_{4}^{+}$ concentration remained relatively constant at $10 \mathrm{mg} \mathrm{N} / \mathrm{L}$ due to the precise periodic dosing of $\mathrm{NH}_{4} \mathrm{HCO}_{3}$, DO was well controlled at designated levels, and $\mathrm{NO}_{3}{ }^{-}$concentration maintained around $1500 \mathrm{mg} \mathrm{N} / \mathrm{L}$, which was consistent with the expectation in the cycle effluent of the SBR. $\mathrm{NO}_{2}{ }^{-}$concentration for all DO levels studied was lower than $0.2 \mathrm{mg} \mathrm{N} / \mathrm{L}$ (see Figure 1), indicating the realization of removing $\mathrm{NO}_{2}{ }^{-}$accumulation in the bulk liquid.

Figure 2 shows the biomass specific AOR and $\mathrm{N}_{2} \mathrm{OR}$ as well as $\mathrm{N}_{2} \mathrm{O}$ emission factor calculated based on the batch experimental results presented in Figure 1. Biomass specific AOR increased with DO but reached a steady level when DO exceeded $2.5 \mathrm{mg} \mathrm{O}_{2} / \mathrm{L}$ (Figure 2A), resulting from 
the limited conversion capacity of AOB in the augmented nitrifying sludge. Biomass specific $\mathrm{N}_{2} \mathrm{OR}$ first increased with DO, peaked at DO of $0.75 \mathrm{mg} \mathrm{O} / \mathrm{L}$ with a value of $3.03 \pm 0.05 \mathrm{mg}$ $\mathrm{N} / \mathrm{h} / \mathrm{g}$ VSS, and thereafter kept decreasing until DO reached the maximum studied level of 3.0 $\mathrm{mg} \mathrm{O}_{2} / \mathrm{L}$ (Figure 2B). As demonstrated in Figure 2C, the correlation between biomass specific $\mathrm{N}_{2} \mathrm{OR}$ and biomass specific AOR was positive when biomass specific AOR was below $22.0 \pm$ $1.2 \mathrm{mg} \mathrm{N} / \mathrm{h} / \mathrm{g}$ VSS, above which biomass specific $\mathrm{N}_{2} \mathrm{OR}$ was negatively correlated to biomass specific AOR. The $\mathrm{N}_{2} \mathrm{O}$ emission factor in Figure 2D exhibited a negative relationship with DO and gradually decreased from $18.6 \pm 0.5 \%$ at the lowest non-zero DO level of $0.2 \mathrm{mg} \mathrm{O}_{2} / \mathrm{L}$ to 4.9 $\pm 0.3 \%$ at the maximum DO level of $3.0 \mathrm{mg} \mathrm{O}_{2} / \mathrm{L}$.

\subsection{Model-based analysis of batch test data to infer $\mathrm{N}_{2} \mathrm{O}$ production pathways}

All the model parameters in Table S3 in the SI were assessed in the sensitivity analysis, with the $\mathrm{N}_{2} \mathrm{O}$ production at five DO levels (i.e., $0.2,0.75,1.0,2.0$ and $3.0 \mathrm{mg} \mathrm{O} / \mathrm{L}$ ) being the model output. Figure S3 in the SI indicates the sensitivity of the $\mathrm{N}_{2} \mathrm{O}$ production to the top six most sensitive model parameters. Among all the parameters, the specific maximum nitrite reduction rate $r_{N O 2, \text { red }}^{A O B}$ was found to exert the most determinant impact on the $\mathrm{N}_{2} \mathrm{O}$ production by $\mathrm{AOB}$ under the batch experimental conditions in this work. Although not the most sensitive one (see Figure S3), the oxygen inhibition constant $K_{I, O 2}^{A O B}$ should also be evaluated, considering its first appearance in the electron carriers-based $\mathrm{N}_{2} \mathrm{O}$ model. Therefore, $r_{N O 2, \text { red }}^{A O B}$ and $K_{I, O 2}^{A O B}$ were chosen to be evaluated in the model calibration and validation process using the batch experimental data obtained in this work. Literature reported values were directly adopted for the remaining parameters in the following modelling process. 
The model calibration and validation process was successfully carried out (see Figure S4 in the SI). As presented in Figures S3A, S3C, S3D, S3F and S3H which show the model calibration results at DO levels of $0.2,0.75,1.0,2.0$ and $3.0 \mathrm{mg} \mathrm{O}_{2} / \mathrm{L}$, respectively, the model captured all the variation profiles including $\mathrm{N}_{2} \mathrm{O}, \mathrm{DO}, \mathrm{NH}_{4}{ }^{+}$and $\mathrm{NO}_{2}{ }^{-}$. The good match proved the validity of the calibrated model. The best fit was obtained when $r_{N O 2, \text { red }}^{A O B}$ equaled $0.52 \pm 0.02 \mathrm{mmol} / \mathrm{mmol}-$ $\mathrm{COD} / \mathrm{h}$ and $K_{I, O 2}^{A O B}$ equaled $0.016 \pm 0.001 \mathrm{mmol} / \mathrm{L}$. Figure S5 in the SI shows the $95 \%$ confidence region for $r_{N O 2, \text { red }}^{A O B}$ and $K_{I, O 2}^{A O B}$ together with their uncorrelated confidence intervals obtained during the model calibration process. The uncorrelated confidence intervals of both parameters were relatively small and mostly covered by the correlated confidence region, indicating a good level of reliability and identifiability of the estimated parameter values. The validity of parameters and structure of the developed model was further supported by the good model validation results in Figures S3B, S3E and S3G corresponding to DO levels of 0.5, 1.5 and 2.5 $\mathrm{mg} \mathrm{O}_{2} / \mathrm{L}$, respectively.

As shown in Figure 3, the developed model could capture the experimentally measured DOdependent $\mathrm{N}_{2} \mathrm{OR}$ to a large degree $\left(\mathrm{R}^{2}=0.88\right)$. The maximum relative error at $\mathrm{DO}$ of $3.0 \mathrm{mg} \mathrm{O} / \mathrm{L}$ was $<20 \%$, which was acceptable in terms of model predictions. In virtue of this, the developed model was used to deduce the contributions of the two pathways to the $\mathrm{N}_{2} \mathrm{O}$ production under different DO concentration conditions. The model predicted results were incorporated into Figure 3. Albeit exhibiting a decreasing trend, the AOB denitrification pathway was dominating (>98.0\%) under all the DO concentration conditions studied in this work, even though there was no significant bulk $\mathrm{NO}_{2}{ }^{-}$accumulation $(<0.2 \mathrm{mg} \mathrm{N} / \mathrm{L})$ in the system. Therefore, the response of the $\mathrm{AOB}$ denitrification pathway to DO was responsible for the trend observed in Figure $2 \mathrm{~B}$. In 
contrast, the contribution of the hydroxylamine pathway to the $\mathrm{N}_{2} \mathrm{O}$ production was minor at all DO levels and increased slightly but consistently from $0.1 \%$ at DO of $0.2 \mathrm{mg} \mathrm{O}_{2} / \mathrm{L}$ to $1.8 \%$ at DO of $3.0 \mathrm{mg} \mathrm{O} / \mathrm{L}$.

\subsection{Nitrite accumulation inside sludge flocs potentially regulating $\mathrm{N}_{2} \mathrm{O}$ production} pathways

Albeit the low bulk $\mathrm{NO}_{2}{ }^{-}$concentration $(<0.2 \mathrm{mg} \mathrm{N} / \mathrm{L})$ observed under all DO concentration conditions (see Figure 1), the mixed liquid at steady state underwent an evident increase in $\mathrm{NO}_{2}{ }^{-}$ concentration from $0.18 \pm 0.03$ to $0.51 \pm 0.05 \mathrm{mg} \mathrm{NO}{ }_{2}^{-}-\mathrm{N} / \mathrm{L}$ after high-output sonication treatment, as shown in Figure 4. However, no change in bulk $\mathrm{NO}_{2}{ }^{-}$concentration was observed for mixed liquid samples taken right after the $\mathrm{NH}_{4}{ }^{+}$stock solution was added at 10 min (data was not shown but post-sonication $\mathrm{NO}_{2}{ }^{-}$concentration remained around 0 ), suggesting no direct $\mathrm{NO}_{2}{ }^{-}$ release due to initial $\mathrm{NO}_{2}^{-}$presence in the floc structure and/or cell lysis. Therefore, this increase in the low bulk $\mathrm{NO}_{2}{ }^{-}$concentration after high-output sonication treatment implied a significant $\mathrm{NO}_{2}{ }^{-}$accumulation inside the nitrifying sludge flocs despite the trace $\mathrm{NO}_{2}{ }^{-}$detected in the bulk liquid outside the sludge flocs. $\mathrm{As}^{-} \mathrm{NO}_{2}^{-}$is a key factor/precursor regulating the $\mathrm{N}_{2} \mathrm{O}$ production from the AOB denitrification pathway, $\mathrm{NO}_{2}{ }^{-}$accumulation inside the sludge flocs might favor the AOB denitrification pathway, which would result in the trends obtained in this work.

Figure 5 delineates the model predicted distribution of $\mathrm{N}_{2} \mathrm{O}$ production pathways in the representative floc structure considering a thickness of $57 \mu \mathrm{m}$ (i.e., half of D50 measured). The $\mathrm{NO}_{2}{ }^{-}$induced $\mathrm{AOB}$ denitrification pathway in the floc was uneven across thickness. At low DO level of $0.2 \mathrm{mg} \mathrm{O}_{2} / \mathrm{L}$, the rate of the AOB denitrification pathway was high in the middle part of 


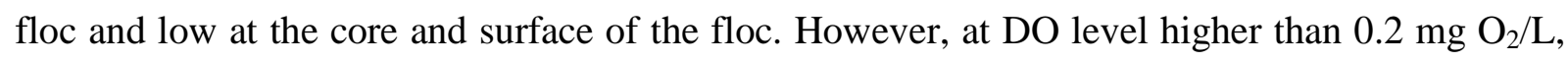
the rate of the $\mathrm{AOB}$ denitrification pathway was highest at the core of floc (i.e., thickness 0 in Figure 5) and decreased gradually towards the floc surface. The overall $\mathrm{N}_{2} \mathrm{O}$ production rate of the AOB denitrification pathway first increased and then decreased with DO, consistent with the finding in Figures 2B and 4. In contrast, the hydroxylamine pathway did not change significantly across thickness and kept increasing with DO level but at rates much lower than the AOB denitrification pathway under all DO concentration conditions studied.

\section{DISCUSSION}

In nitrifying sludge, microbial activities mainly take place inside flocs. Intermediates are produced inside flocs and then diffuse into the bulk liquid, leading to possible substrate concentration gradient. Therefore, the concentration of $\mathrm{NO}_{2}^{-}$produced by $\mathrm{AOB}$ inside the nitrifying sludge flocs might be higher than that measured in the bulk liquid, resulting in $\mathrm{N}_{2} \mathrm{O}$ production even in the absence of significant $\mathrm{NO}_{2}{ }^{-}$detected in the bulk liquid. However, to date no work has been done to elucidate the role of the potential nitrite accumulation inside sludge flocs in $\mathrm{N}_{2} \mathrm{O}$ production by $\mathrm{AOB}$ at different DO levels, due to the interferences of either heterotrophic contribution in the sludge (Tallec et al. 2006, Wunderlin et al. 2012, Yang et al. 2009) or accompanying $\mathrm{NO}_{2}{ }^{-}$accumulation in bulk liquid (e.g., $1.5 \sim 2.0 \mathrm{mg} \mathrm{NO}_{2}{ }^{-} \mathrm{-N} / \mathrm{L}$ in Peng et al. (2014)). To deal with these two interferences, an augmented nitrifying sludge with higher abundance of NOB than AOB in sludge flocs was enriched in this work. Through applying this augmented nitrifying sludge, the interference from heterotrophic denitrification was eliminated, which was supported by both the control phase data in Figure 1 and the results of $\mathrm{N}_{2} \mathrm{O}$ consumption control tests in Figure S2. The existence of substrate concentration gradient was 
400

401

402

403

404

405

406

407

408

409

410

411

412

413

414

415

416

417

418

419

420

421

422

verified by Figure S6 in the SI which showed the model predicted profiles in the representative sludge floc at bulk DO concentration of $2.0 \mathrm{mg} \mathrm{O} / \mathrm{L}$. The $\mathrm{NO}_{2}{ }^{-}$accumulation in the bulk liquid at all DO levels studied in this work was well controlled at very low levels $\left(<0.2 \mathrm{mg} \mathrm{NO}_{2}{ }^{-} \mathrm{N} / \mathrm{L}\right.$ in Figures 1 and 4), thus minimizing the interference from accompanying significant bulk $\mathrm{NO}_{2}^{-}$ accumulation. The results demonstrated that the AOB denitrification pathway for $\mathrm{N}_{2} \mathrm{O}$ production was dominant $(98.0 \%)$ at all DO levels tested even without significant bulk $\mathrm{NO}_{2}{ }^{-}$ accumulation $(<0.2 \mathrm{mg} \mathrm{N} / \mathrm{L})$ observed in the system, which was in fact due to the nitrite accumulation which existed inside the sludge flocs and therefore induced significant $\mathrm{N}_{2} \mathrm{O}$ production from the $\mathrm{AOB}$ denitrification pathway.

The maximum specific AOR in this work ( $\sim 35 \mathrm{mg} \mathrm{N} / \mathrm{h} / \mathrm{g}$ VSS in Figure $2 \mathrm{~A})$ was lower than the one obtained in Peng et al. (2014) ( $74 \mathrm{mg} \mathrm{N} / \mathrm{h} / \mathrm{g}$ VSS). One reason could be the lower abundance of AOB (i.e., $35 \pm 3 \%$ based on the FISH analysis) in the augmented nitrifying sludge used in this work. The trends in Figures $2 \mathrm{~B}$ and $2 \mathrm{C}$ revealed that DO level higher than $0.75 \mathrm{mg}$ $\mathrm{O}_{2} / \mathrm{L}$ would exhibit an inhibitive effect on the $\mathrm{N}_{2} \mathrm{O}$ production by $\mathrm{AOB}$, irrespective of higher biomass specific AOR induced. The DO level for maximum $\mathrm{N}_{2} \mathrm{O}$ production located in this work (i.e., $0.75 \mathrm{mg} \mathrm{O}_{2} / \mathrm{L}$ ) was close to the reported $\mathrm{DO}$ level of $0.85-1.0 \mathrm{mg} \mathrm{O}_{2} / \mathrm{L}$ by some studies of similar interest (Peng et al. 2015, Tallec et al. 2006, Yang et al. 2009). Although the relationship between $\mathrm{N}_{2} \mathrm{O}$ production by $\mathrm{AOB}$ and $\mathrm{DO}$ was similar, the bulk $\mathrm{NO}_{2}{ }^{-}$concentration in this work (i.e., $0.18 \pm 0.03 \mathrm{mg} \mathrm{NO}_{2}^{-}-\mathrm{N} / \mathrm{L}$ ) was much lower than Peng et al. (2015) which dosed external $\mathrm{NO}_{2}{ }^{-}$to maintain a constant level of $3-50 \mathrm{mg} \mathrm{NO}{ }^{-}-\mathrm{N} / \mathrm{L}$ in the bulk liquid. As presented in Figure 4, a significant increase from $0.18 \pm 0.03$ to $0.51 \pm 0.05 \mathrm{mg} \mathrm{NO}_{2}{ }^{-} \mathrm{N} / \mathrm{L}$ was observed in the bulk $\mathrm{NO}_{2}{ }^{-}$concentration after high-output sonication was applied, implying a significant 
level of $\mathrm{NO}_{2}{ }^{-}$accumulation in the nitrifying sludge flocs. The $\mathrm{NO}_{2}{ }^{-}$accumulated in the sludge flocs could explain the model predicted dominant role of the AOB denitrification pathway in $\mathrm{N}_{2} \mathrm{O}$ production by AOB in Figure 3, even though the bulk $\mathrm{NO}_{2}{ }^{-}$concentration was extremely low. The noticeable discrepancy between experimentally observed and model predicted $\mathrm{N}_{2} \mathrm{OR}$ at DO concentrations of 2.5 and $3.0 \mathrm{mg} \mathrm{O}_{2} / \mathrm{L}$ in Figure 3 might be due to the possible existence of other minor $\mathrm{N}_{2} \mathrm{O}$ contributing pathways at relatively high DO concentrations such as abiotic $\mathrm{N}_{2} \mathrm{O}$ production (Liu et al. 2017) and AOA associated $\mathrm{N}_{2} \mathrm{O}$ production pathway (Hu et al. 2015). However, the overall good match between experimentally observed and model predicted data (as evidenced by the correlation factor of 0.98 and $\mathrm{R}^{2}$ of 0.88 ) together with the dominance of $\mathrm{AOB}$ and NOB in the augmented nitrifying sludge confirmed the validity of $\mathrm{AOB}$ associated $\mathrm{N}_{2} \mathrm{O}$ dynamics reported in this work. Given that the bulk $\mathrm{NO}_{2}^{-}$concentrations before and after sonication were low and similar at different DO levels (see Figure 4), the differences in $\mathrm{N}_{2} \mathrm{O}$ production in different batch tests of this work could still be reliably attributed to DO variation. As indicated in Figure 3, the AOB denitrification pathway contributed the most (>98.0\%) to $\mathrm{N}_{2} \mathrm{O}$ production under the DO concentration conditions studied in this work. Therefore, the shift in the biomass specific $\mathrm{N}_{2} \mathrm{OR}$ with DO in Figure 3 to great extent profiled the DO-dependent rate of the AOB denitrification pathway. Although the rate of the AOB denitrification was stimulated at low DO levels but got inhibited after DO exceeded $0.75 \mathrm{mg} \mathrm{O}_{2} / \mathrm{L}$, its contribution to $\mathrm{N}_{2} \mathrm{O}$ production decreased consistently with DO, due to the increased contribution of the hydroxylamine pathway on which DO had a positive effect (see Figure 3). Though the positive relationship between $\mathrm{N}_{2} \mathrm{O}$ production from the hydroxylamine pathway and DO was commensurate with Peng et al. (2015) and Peng et al. (2014), the contribution was much lower in this work (maximum share of only $1.8 \%$ at the highest studied DO level of $3.0 \mathrm{mg} \mathrm{O}_{2} / \mathrm{L}$ ). 
The impact of DO on the $\mathrm{N}_{2} \mathrm{O}$ production observed in Figure 3 could also be explained using model kinetics. The calibrated oxygen inhibition constant for the AOB denitrification pathway

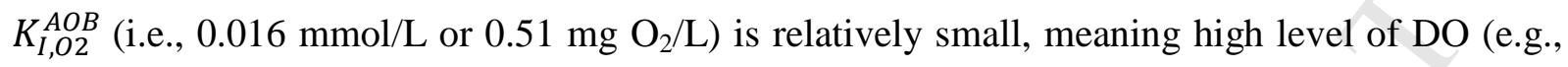
$0.75 \mathrm{mg} \mathrm{O} / 2$ in this work) would definitely inhibit $\mathrm{N}_{2} \mathrm{O}$ production by the AOB denitrification pathway. When the DO inhibition was not significant (e.g., at DO level of 0.2 or $0.5 \mathrm{mg} \mathrm{O}_{2} / \mathrm{L}$ ), the elevation in DO would enhance $\mathrm{NH}_{4}{ }^{+}$and hence $\mathrm{NH}_{2} \mathrm{OH}$ oxidation, thus rendering more electron supply for both pathways. Consequently, the rates of both pathways increased. In addition to the direct inhibition of DO on the microbial activity via the AOB denitrification pathway, the negative impact of DO level of higher than $0.75 \mathrm{mg} \mathrm{O}_{2} / \mathrm{L}$ on $\mathrm{N}_{2} \mathrm{O}$ production by the AOB denitrification pathway would be intensified considering the one order of magnitude difference in Mred affinity constants for oxygen reduction $K_{M r e d, 3}($ i.e., $0.78 \mathrm{mmol} / \mathrm{mmol}-\mathrm{COD}$ ) and $\mathrm{NO}_{2}{ }^{-}$reduction $K_{M r e d, 4}$ (i.e., $2.1 \mathrm{mmol} / \mathrm{mmol}-\mathrm{COD}$ ). $K_{\text {Mred }}$ represents the affinity of the corresponding reduction reaction to Mred, with lower value indicating a higher affinity and thus a higher ability to compete for electrons. Therefore, on the premise of the comparable specific maximum rates for oxygen reduction $r_{O 2 \text {,red }}^{A O B}$ (i.e., $0.54 \mathrm{mmol} / \mathrm{mmol}-\mathrm{COD} / \mathrm{h}$ ) and $\mathrm{NO}_{2}{ }^{-}$reduction $r_{N O 2, \text { red }}^{A O B}$ (i.e., $0.52 \mathrm{mmol} / \mathrm{mmol}-\mathrm{COD} / \mathrm{h}$ ), increased AOR with higher DO would render more electrons for oxygen reduction to $\mathrm{H}_{2} \mathrm{O}$ and less for the AOB denitrification pathway for $\mathrm{N}_{2} \mathrm{O}$ production. This explanation agreed well with the assumption made by Li et al. (2015). As Mred affinity constant for NO reduction $K_{M r e d, 2}$ (i.e., $1.1 \times 10^{-4} \mathrm{mmol} / \mathrm{mmol}-\mathrm{COD}$ ) is four orders of magnitude lower than that for nitrite reduction $K_{M r e d, 4}\left(\right.$ i.e., $2.1 \mathrm{mmol} / \mathrm{mmol}-\mathrm{COD}$ ), the $\mathrm{NH}_{2} \mathrm{OH}$ 467 pathway has a higher ability than the AOB denitrification pathway to compete for electrons for $468 \mathrm{~N}_{2} \mathrm{O}$ production. Therefore, the adversely affected $\mathrm{N}_{2} \mathrm{O}$ production by the AOB denitrification 
pathway at DO level of higher than $0.75 \mathrm{mg} \mathrm{O} / \mathrm{L}$ would divert more electrons for $\mathrm{N}_{2} \mathrm{O}$ production by the $\mathrm{NH}_{2} \mathrm{OH}$ pathway, leading to the increased $\mathrm{N}_{2} \mathrm{O}$ production by the $\mathrm{NH}_{2} \mathrm{OH}$ pathway in Figure 3. However, as the calibrated value of specific maximum nitrite reduction rate $r_{N O 2, \text { red }}^{A O B}$ (i.e., $0.52 \mathrm{mmol} / \mathrm{mmol}-\mathrm{COD} / \mathrm{h}$ ) is three orders of magnitude higher than the value of the specific maximum NO reduction rate $r_{N O \text {,red }}^{A O B}$ (i.e., $1.8 \times 10^{-4} \mathrm{mmol} / \mathrm{mmol}-\mathrm{COD} / \mathrm{h}$ ), the AOB denitrification pathway was still prevailing $(>98.0 \%)$ under the DO concentration conditions studied in this work (see Figure 3).

This finding pertaining to $\mathrm{N}_{2} \mathrm{OR}$ was significantly different from Peng et al. (2014) reporting a positive relationship between $\mathrm{N}_{2} \mathrm{OR}$ and DO which might be ascribed to the difference in microbial and floc structure as well as dominant $\mathrm{N}_{2} \mathrm{O}$ production pathway(s) involved. Despite the discrepancy in $\mathrm{N}_{2} \mathrm{OR}$, the negative dependence of the overall $\mathrm{N}_{2} \mathrm{O}$ emission factor on DO and the magnitude of $\mathrm{N}_{2} \mathrm{O}$ emission factor at corresponding DO level in Figure 2D were still commensurate with Peng et al. (2014). Overall, a moderate DO level (e.g., $3.0 \mathrm{mg} \mathrm{O} / 2$ in this work) is needed in order to maximize the capacity of $\mathrm{AOB}$ whilst reducing $\mathrm{N}_{2} \mathrm{O}$ production by AOB.

This work also confirmed the necessity of modelling the nitrifying sludge flocs as a particle system when considering intermediates (e.g., $\mathrm{NO}_{2}{ }^{-}$and $\mathrm{NH}_{2} \mathrm{OH}$ ), especially at low concentrations. More insight into the true niche where microbial activities take place could be only revealed when treating the nitrifying sludge flocs as a particle system. As demonstrated in Figure 4, even though bulk nitrite concentration was low, nitrite accumulation because of microbial activities as well as substrate diffusion existed inside the sludge flocs. It was this part 
492

493

494

495

496

497

498

499

500

501

502

503

504

505

506

507

508

509

510

511

512

513

514

of nitrite accumulation inside the sludge flocs that induced stratification of $\mathrm{N}_{2} \mathrm{O}$ production by the AOB denitrification pathway in Figure 5 and hence the overall $\mathrm{N}_{2} \mathrm{O}$ production trend in Figure 3. However, this stratified phenomenon couldn't be captured if the sludge flocs were modelled as a completely mixed suspended system, where uniform concentration was assumed and $\mathrm{N}_{2} \mathrm{O}$ production due to nitrite accumulation inside the nitrifying sludge flocs might be overlooked. From the perspective of practical application, the significant role of nitrite accumulation inside the sludge flocs in $\mathrm{N}_{2} \mathrm{O}$ production revealed in this work underpinned the coupling of nitritation with denitritation or anaerobic ammonium oxidation (anammox) in onestage systems. Despite the well-known advantages in reduced energy demands, this advanced nitrogen removal technology would realize in-situ nitrite consumption inside the sludge flocs and thus reduce $\mathrm{N}_{2} \mathrm{O}$ production/emission. A modelling study by Sabba et al. (2015) also suggested that $\mathrm{N}_{2} \mathrm{O}$ production from nitrifying biofilms could be significantly greater than from suspended growth systems under similar conditions, mainly due to the important role of intermediate diffusion in the attached form. The consideration of the nitrifying sludge flocs as a particle system with substrate diffusion in the $\mathrm{N}_{2} \mathrm{O}$ pathway model would be of particular interest when it comes to developing viable control technologies for reducing $\mathrm{N}_{2} \mathrm{O}$ production/emission in nitrogen removal systems, as most reported model-based studies focusing on $\mathrm{N}_{2} \mathrm{O}$ control (such as Behera et al. (2015) and Boiocchi et al. (2017)) didn't take into account the role of floccular structure of nitrifying sludge.

It should be highlighted that the obtained results with respect to the impact of potential nitrite accumulation inside sludge flocs on $\mathrm{N}_{2} \mathrm{O}$ production could be generalized considering the comparable physicochemical properties of the augmented nitrifying sludge flocs to the typical 
515

516

517

518

519

520

521

activated sludge flocs. It is also acknowledged that the contributions of the two $\mathrm{N}_{2} \mathrm{O}$ production pathways were only calculated using mathematical modelling in this work. Though direct quantification using isotopic analysis is possible, further improvement in the accuracy and reliability of this technology is needed (Duan et al. 2017).

\section{CONCLUSIONS}

This work clarified the role of potential $\mathrm{NO}_{2}{ }^{-}$accumulation inside sludge flocs in $\mathrm{N}_{2} \mathrm{O}$ production by $\mathrm{AOB}$ at different $\mathrm{DO}$ levels with focus on the conditions of no significant bulk $\mathrm{NO}_{2}^{-}$ accumulation $(<0.2 \mathrm{mg} \mathrm{N} / \mathrm{L})$. The biomass specific $\mathrm{N}_{2} \mathrm{O}$ production rate firstly increased and then decreased with DO, with the maximum value of $3.03 \pm 0.05 \mathrm{mg} \mathrm{N} / \mathrm{h} / \mathrm{g}$ VSS obtained at DO level of $0.75 \mathrm{mg} \mathrm{O}_{2} / \mathrm{L}$. The $\mathrm{AOB}$ denitrification pathway for $\mathrm{N}_{2} \mathrm{O}$ production was dominant $(98.0 \%)$ at all DO levels tested even without significant bulk $\mathrm{NO}_{2}{ }^{-}$accumulation $(<0.2 \mathrm{mg} \mathrm{N} / \mathrm{L})$ observed in the system, but its contribution decreased with DO. DO had a positive impact on the hydroxylamine pathway for $\mathrm{N}_{2} \mathrm{O}$ production which therefore increased with DO. The nitrite accumulation existed inside the sludge flocs and induced significant $\mathrm{N}_{2} \mathrm{O}$ production from the AOB denitrification pathway. The findings not only highlighted the importance of achieving insitu $\mathrm{NO}_{2}^{-}$consumption inside sludge flocs in reducing $\mathrm{N}_{2} \mathrm{O}$ production/emission, but also underpinned the necessity of considering the floccular sludge structure in the model when developing $\mathrm{N}_{2} \mathrm{O}$ control strategies.

\section{ACKNOWLEDGEMENTS}


This study was supported by the Australian Research Council (ARC) through Future Fellowship FT160100195. The authors acknowledge the assistance of Haoran Duan and Jiaoyang Pu at The University of Queensland in the FISH and pyrosequencing analyses.

\section{REFERENCES}

APHA (1998) Standard methods for the examination of water and wastewater, American Public Health Association, Washington, DC.

Batstone, D.J., Pind, P.F. and Angelidaki, I. (2003) Kinetics of thermophilic, anaerobic oxidation of straight and branched chain butyrate and valerate. Biotechnology and Bioengineering 84(2), 195-204.

Behera, C.R., Srinivasan, B., Chandran, K. and Venkatasubramanian, V. (2015) Model based predictive control for energy efficient biological nitrification process with minimal nitrous oxide production. Chemical Engineering Journal 268, 300-310.

Boiocchi, R., Gernaey, K.V. and Sin, G. (2017) A novel fuzzy-logic control strategy minimizing N2O emissions. Water Research 123, 479-494.

Chandran, K., Stein, L.Y., Klotz, M.G. and van Loosdrecht, M.C.M. (2011) Nitrous oxide production by lithotrophic ammonia-oxidizing bacteria and implications for engineered nitrogen-removal systems. Biochemical Society Transactions 39, 1832-1837.

Contreras, E.M., Bertola, N.C., Giannuzzi, L. and Zaritzky, N.E. (2002) A modified method to determine biomass concentration as COD in pure cultures and in activated sludge systems. Water Sa 28(4), 463-468. 
Daims, H., Nielsen, J.L., Nielsen, P.H., Schleifer, K.-H. and Wagner, M. (2001) In Situ Characterization ofNitrospira-Like Nitrite-Oxidizing Bacteria Active in Wastewater Treatment Plants. Applied and Environmental Microbiology 67(11), 5273-5284.

Duan, H., Ye, L., Erler, D., Ni, B.-J. and Yuan, Z. (2017) Quantifying nitrous oxide production pathways in wastewater treatment systems using isotope technology - A critical review. Water Research 122(Supplement C), 96-113.

Foley, J., de Haas, D., Yuan, Z. and Lant, P. (2010) Nitrous oxide generation in full-scale biological nutrient removal wastewater treatment plants. Water Research 44(3), 831-844.

Ge, H., Jensen, P.D. and Batstone, D.J. (2010) Pre-treatment mechanisms during thermophilicmesophilic temperature phased anaerobic digestion of primary sludge. Water Research 44(1), $123-130$.

Gong, Y.K., Wang, S.Y., Wang, S. and Peng, Y.Z. (2012) Nitrous oxide production from sequencing batch reactor sludge under nitrifying conditions: effect of nitrite concentrations. Environmental Technology 33(4), 401-408.

Hu, H.-W., Chen, D. and He, J.-Z. (2015) Microbial regulation of terrestrial nitrous oxide formation: understanding the biological pathways for prediction of emission rates. FEMS Microbiology Reviews 39(5), 729-749.

Hülsen, T., Barry, E.M., Lu, Y., Puyol, D., Keller, J. and Batstone, D.J. (2016) Domestic wastewater treatment with purple phototrophic bacteria using a novel continuous photo anaerobic membrane bioreactor. Water Research 100(Supplement C), 486-495.

IPCC (2013) Climate Change 2013: The Physical Science Basis. Contribution of Working Group I to the Fifth Assessment Report of the Intergovernmental Panel on Climate Change, Cambridge University Press, Cambridge, United Kingdom and New York, NY, USA. 
Kampschreur, M.J., Poldermans, R., Kleerebezem, R., van der Star, W.R.L., Haarhuis, R., Abma, W.R., Jetten, M.S.M. and van Loosdrecht, M.C.M. (2009) Emission of nitrous oxide and nitric oxide from a full-scale single-stage nitritation-anammox reactor. Water Science and Technology 60(12), 3211-3217.

Kampschreur, M.J., Tan, N.C.G., Kleerebezem, R., Picioreanu, C., Jetten, M.S.M. and Loosdrecht, M.C.M. (2008) Effect of dynamic process conditions on nitrogen oxides emission from a nitrifying culture. Environmental Science \& Technology 42(2), 429-435.

Kim, S.-W., Miyahara, M., Fushinobu, S., Wakagi, T. and Shoun, H. (2010) Nitrous oxide emission from nitrifying activated sludge dependent on denitrification by ammonia-oxidizing bacteria. Bioresource Technology 101(11), 3958-3963.

Koch, G., Egli, K., Van der Meer, J.R. and Siegrist, H. (2000) Mathematical modeling of autotrophic denitrification in a nitrifying biofilm of a rotating biological contactor. Water Science and Technology 41(4-5), 191-198.

Law, Y., Lant, P. and Yuan, Z. (2013) The confounding effect of nitrite on N2O production by an enriched ammonia-oxidizing culture. Environmental Science and Technology 47(13), 7186-7194.

Law, Y., Lant, P. and Yuan, Z.G. (2011) The effect of pH on N2O production under aerobic conditions in a partial nitritation system. Water Research 45(18), 5934-5944.

Law, Y., Ni, B.-J., Lant, P. and Yuan, Z. (2012) N2O production rate of an enriched ammoniaoxidising bacteria culture exponentially correlates to its ammonia oxidation rate. Water Research 46(10), 3409-3419.

Li, B. and Bishop, P. (2003a) Structure-function dynamics and modeling analysis of the microenvironment of activated sludge floc. Water Science and Technology 47(11), 267-273. 
603

604

605

606

607

608

609

610

611

612

613

614

615

616

617

618

619

620

621

622

623

624

Li, B. and Bishop, P.L. (2003b) Modeling of the microenvironment of activated sludge floc with experimental and theoretical methods. Journal of Environmental Engineering and Science 2(1), 27-37.

Li, P., Wang, S., Peng, Y., Liu, Y. and He, J. (2015) The synergistic effects of dissolved oxygen and $\mathrm{pH}$ on $\mathrm{N} 2 \mathrm{O}$ production in biological domestic wastewater treatment under nitrifying conditions. Environmental Technology 36(13), 1623-1631.

Liu, S., Han, P., Hink, L., Prosser, J.I., Wagner, M. and Brüggemann, N. (2017) Abiotic Conversion of Extracellular $\mathrm{NH} 2 \mathrm{OH}$ Contributes to $\mathrm{N} 2 \mathrm{O}$ Emission during Ammonia Oxidation. Environmental Science \& Technology 51(22), 13122-13132.

Massara, T.M., Malamis, S., Guisasola, A., Baeza, J.A., Noutsopoulos, C. and Katsou, E. (2017) A review on nitrous oxide (N2O) emissions during biological nutrient removal from municipal wastewater and sludge reject water. Science of the Total Environment 596, 106123.

Mozo, I., Lesage, N., Sperandio, M. and Bessiere, Y. (2016) Impact of sonication on activated sludge properties and consequences on PAH partitioning. The Canadian Journal of Chemical Engineering 94(2), 244-252.

Ni, B.-J., Chen, Y.-P., Liu, S.-Y., Fang, F., Xie, W.-M. and Yu, H.-Q. (2009) Modeling a granule-based anaerobic ammonium oxidizing (ANAMMOX) process. Biotechnology and Bioengineering 103(3), 490-499.

Ni, B.J., Peng, L., Law, Y.Y., Guo, J.H. and Yuan, Z.G. (2014) Modeling of Nitrous Oxide Production by Autotrophic Ammonia-Oxidizing Bacteria with Multiple Production Pathways. Environmental Science \& Technology 48(7), 3916-3924. 
Ni, B.J., Ruscalleda, M., Pellicer-Nacher, C. and Smets, B.F. (2011) Modeling Nitrous Oxide Production during Biological Nitrogen Removal via Nitrification and Denitrification: Extensions to the General ASM Models. Environmental Science \& Technology 45(18), $7768-7776$.

Peng, L., Ni, B.-J., Erler, D., Ye, L. and Yuan, Z. (2014) The effect of dissolved oxygen on N2O production by ammonia-oxidizing bacteria in an enriched nitrifying sludge. Water Research $(0)$.

Peng, L., Ni, B.-J., Ye, L. and Yuan, Z. (2015) The combined effect of dissolved oxygen and nitrite on $\mathrm{N} 2 \mathrm{O}$ production by ammonia oxidizing bacteria in an enriched nitrifying sludge. Water Research 73(0), 29-36.

Pocquet, M., Wu, Z., Queinnec, I. and Spérandio, M. (2016) A two pathway model for N2O emissions by ammonium oxidizing bacteria supported by the $\mathrm{NO} / \mathrm{N} 2 \mathrm{O}$ variation. Water Research 88(Supplement C), 948-959.

Ravishankara, A.R., Daniel, J.S. and Portmann, R.W. (2009) Nitrous Oxide (N2O): The Dominant Ozone-Depleting Substance Emitted in the 21 st Century. Science 326(5949), 123.

Reichert, P. (1998) AQUASIM 2.0-Computer program for the identification and simulation of aquatic systems, EAWAG, Dubendorf, Switzerland.

Sabba, F., Picioreanu, C., Pérez, J. and Nerenberg, R. (2015) Hydroxylamine Diffusion Can Enhance N2O Emissions in Nitrifying Biofilms: A Modeling Study. Environmental Science \& Technology 49(3), 1486-1494.

Salsabil, M.R., Prorot, A., Casellas, M. and Dagot, C. (2009) Pre-treatment of activated sludge: Effect of sonication on aerobic and anaerobic digestibility. Chemical Engineering Journal 148(2), 327-335. 
648

649

650

651

652

653

654

655

656

657

658

659

660

661

662

663

664

665

666

667

668

669

670

Shen, L., Guan, Y., Wu, G. and Zhan, X. (2014) N2O emission from a sequencing batch reactor for biological $\mathrm{N}$ and $\mathrm{P}$ removal from wastewater. Frontiers of Environmental Science \& Engineering 8(5), 776-783.

Shiskowski, D.M. and Mavinic, D.S. (2006) The influence of nitrite and pH (nitrous acid) on aerobic-phase, autotrophic $\mathrm{N} 2 \mathrm{O}$ generation in a wastewater treatment bioreactor. Journal of Environmental Engineering and Science 5(4), 273-283.

Strokal, M. and Kroeze, C. (2014) Nitrous oxide (N2O) emissions from human waste in 19702050. Current Opinion in Environmental Sustainability 9, 108-121.

Su, Q., Ma, C., Domingo-Félez, C., Kiil, A.S., Thamdrup, B., Jensen, M.M. and Smets, B.F. (2017) Low nitrous oxide production through nitrifier-denitrification in intermittent-feed high-rate nitritation reactors. Water Research 123, 429-438.

Tallec, G., Garnier, J., Billen, G. and Gousailles, M. (2006) Nitrous oxide emissions from secondary activated sludge in nitrifying conditions of urban wastewater treatment plants: Effect of oxygenation level. Water Research 40(15), 2972-2980.

Volcke, E.I.P., Picioreanu, C., De Baets, B. and van Loosdrecht, M.C.M. (2010) Effect of granule size on autotrophic nitrogen removal in a granular sludge reactor. Environmental Technology 31(11), 1271-1280.

Wunderlin, P., Mohn, J., Joss, A., Emmenegger, L. and Siegrist, H. (2012) Mechanisms of N2O production in biological wastewater treatment under nitrifying and denitrifying conditions. Water Research 46(4), 1027-1037.

Yang, Q., Liu, X., Peng, C., Wang, S., Sun, H. and Peng, Y. (2009) N2O Production during Nitrogen Removal via Nitrite from Domestic Wastewater: Main Sources and Control Method. Environmental Science \& Technology 43(24), 9400-9406. 

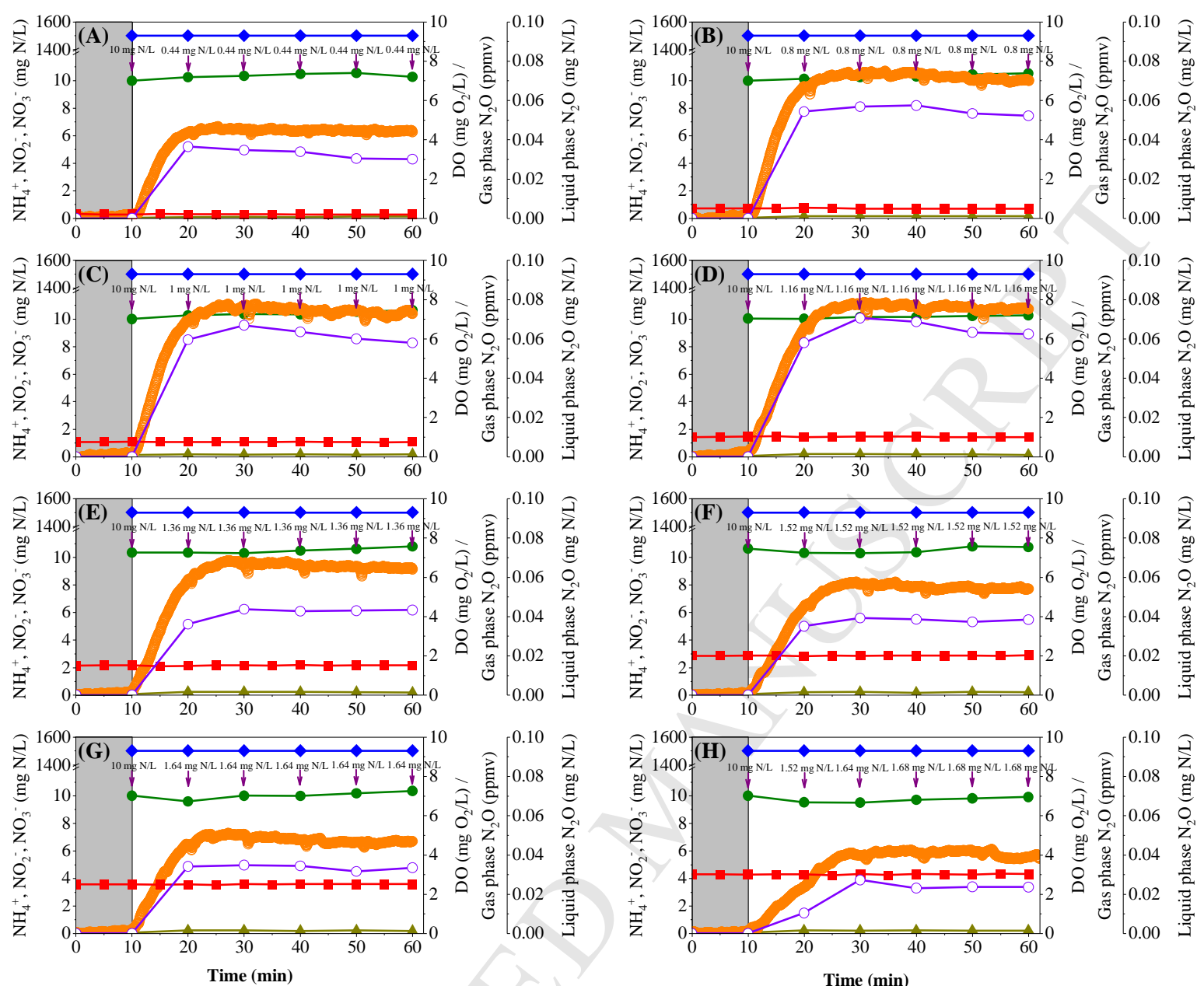

$\multimap \mathrm{NH}_{4}^{+} \longrightarrow \mathrm{NO}_{2}^{-} \longrightarrow \mathrm{NO}_{3}^{-} \rightarrow$ DO $\longrightarrow-$ Liquid phase $\mathrm{N}_{2} \mathrm{O} \quad \circ \quad$ Gas phase $\mathrm{N}_{2} \mathrm{O}$

Figure 1. Levels of gas phase $\mathrm{N}_{2} \mathrm{O}$, liquid phase $\mathrm{N}_{2} \mathrm{O}, \mathrm{NH}_{4}{ }^{+}, \mathrm{NO}_{2}{ }^{-}$and $\mathrm{NO}_{3}{ }^{-}$in batch tests at DO concentrations of (A) $0.2 \mathrm{mg} \mathrm{O}_{2} / \mathrm{L}$, (B) $0.5 \mathrm{mg} \mathrm{O}_{2} / \mathrm{L}$, (C) $0.75 \mathrm{mg} \mathrm{O}_{2} / \mathrm{L}$, (D) $1.0 \mathrm{mg} \mathrm{O}_{2} / \mathrm{L}$, (E) 1.5 $\mathrm{mg} \mathrm{O}_{2} / \mathrm{L}$, (F) $2.0 \mathrm{mg} \mathrm{O}_{2} / \mathrm{L}$, (G) $2.5 \mathrm{mg} \mathrm{O}_{2} / \mathrm{L}$ and (H) $3.0 \mathrm{mg} \mathrm{O}_{2} / \mathrm{L}$. 

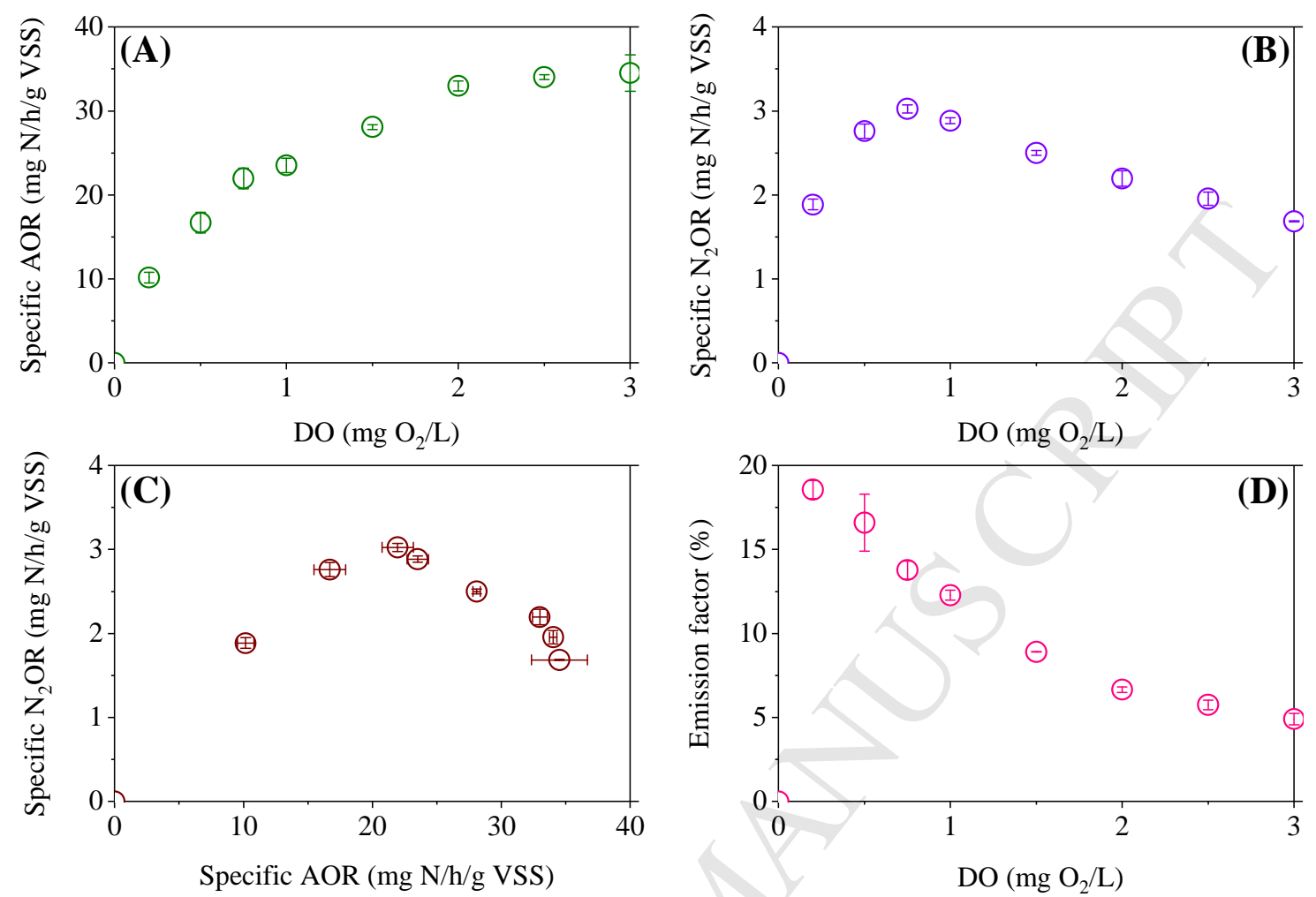

Figure 2. Relationships between (A) AOR and DO, (B) $\mathrm{N}_{2} \mathrm{OR}$ and DO, (C) $\mathrm{N}_{2} \mathrm{OR}$ and AOR and (D) $\mathrm{N}_{2} \mathrm{O}$ emission factor and DO detected in batch tests (error bars stand for standard deviation, $n=3)$. 

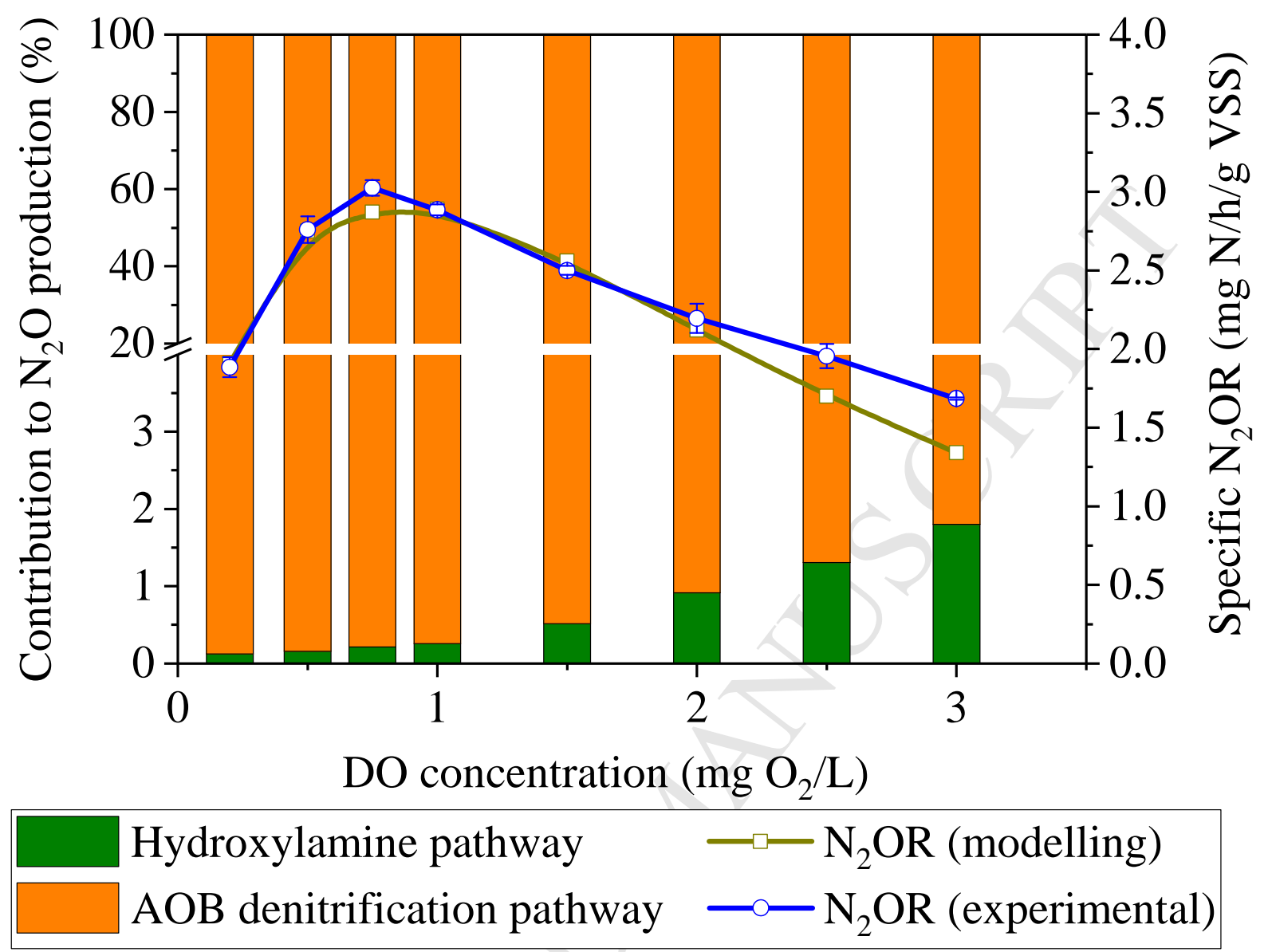

Figure 3. Experimentally observed and model predicted $\mathrm{N}_{2} \mathrm{OR}$ as well as model predicted contribution of the two pathways to $\mathrm{N}_{2} \mathrm{O}$ production at different DO concentrations. 


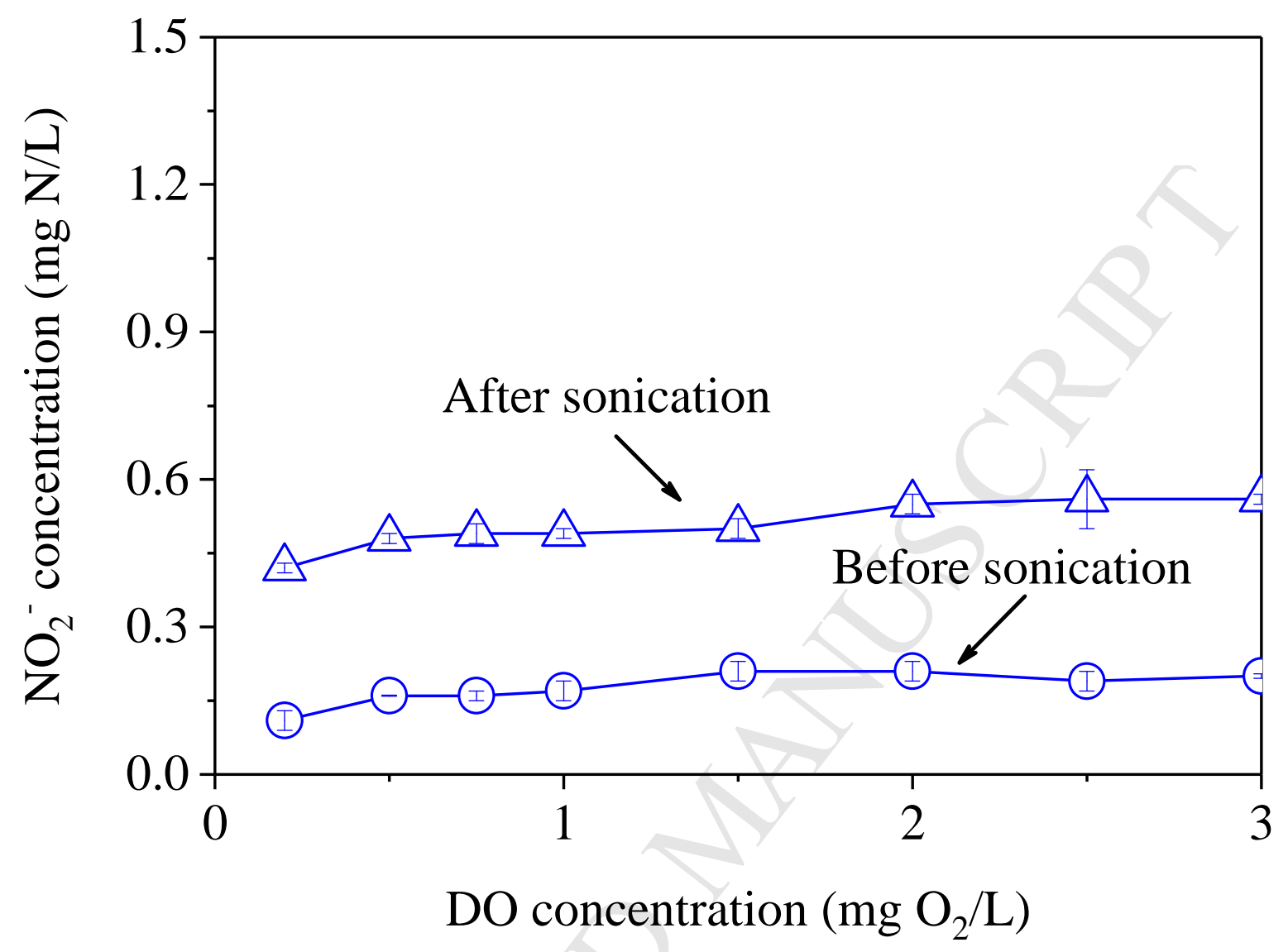

Figure 4. Bulk $\mathrm{NO}_{2}{ }^{-}$concentration before and after sonication at different DO levels. 


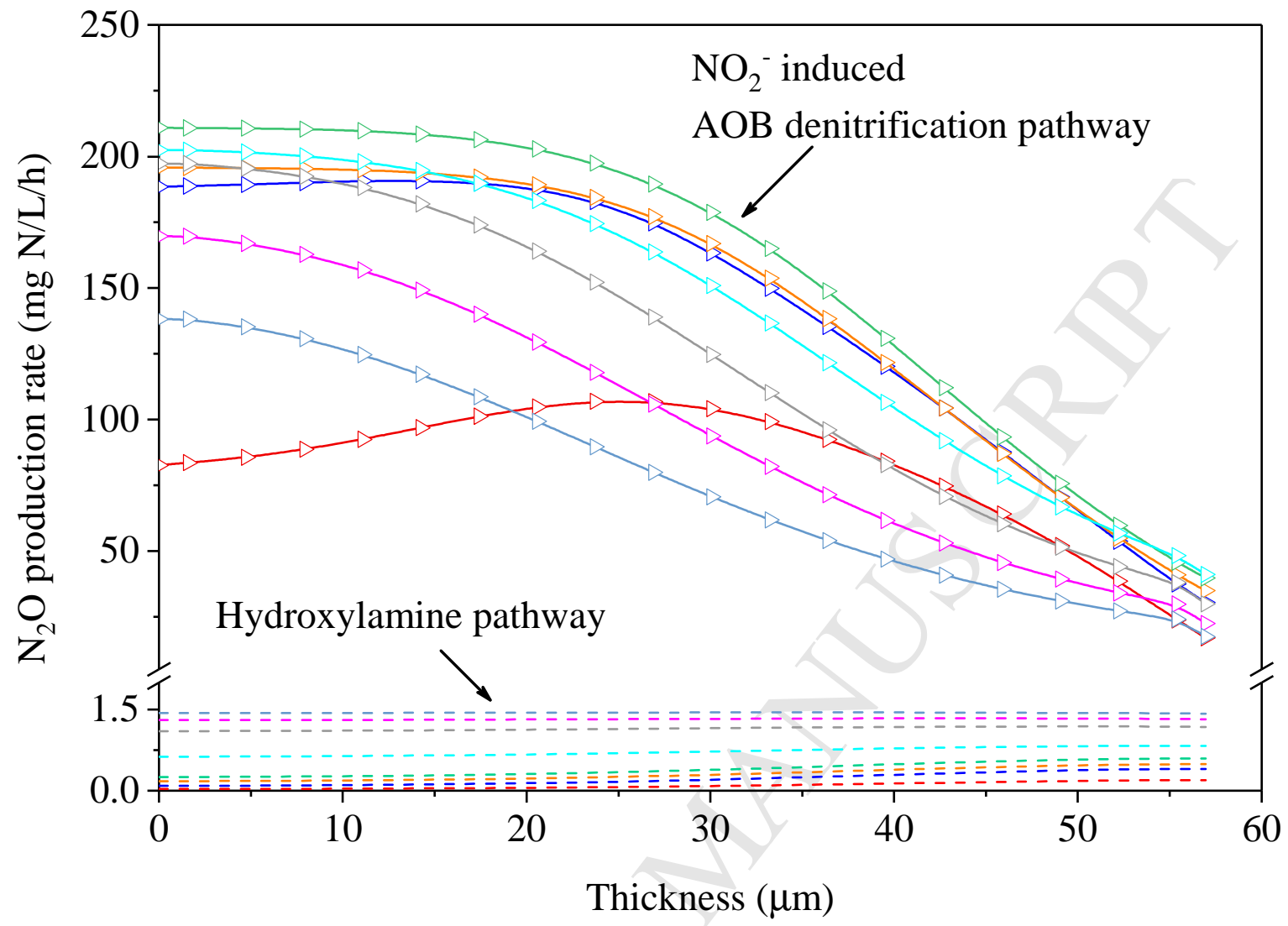

DO levels $\left(\mathrm{mg} \mathrm{O}_{2} / \mathrm{L}\right)$ :

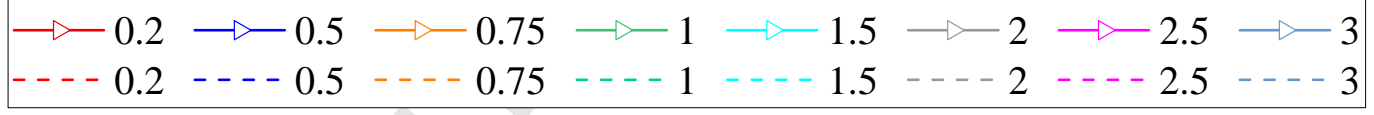

Figure 5. Model predicted distribution of $\mathrm{N}_{2} \mathrm{O}$ production rates in the representative sludge floc. 


\section{Highlights}

$>\quad$ Study on effect of $\mathrm{DO}$ on $\mathrm{N}_{2} \mathrm{O}$ production by $\mathrm{AOB}$ without significant bulk $\mathrm{NO}_{2}{ }^{-}$ accumulation.

$>$ Evaluation and application of a two-pathway model to distinguish $\mathrm{N}_{2} \mathrm{O}$ production.

$>\quad$ DO stimulated $\mathrm{NH}_{2} \mathrm{OH}$ pathway but $\mathrm{AOB}$ denitrification pathway dominated (98\%).

$>\mathrm{NO}_{2}{ }^{-}$accumulation inside sludge flocs significantly affected $\mathrm{N}_{2} \mathrm{O}$ production by AOB. 